\title{
Factors that condition physical vulnerability to ground fracturing in Mexico City
}

\author{
Dora Carreon-Freyre ${ }^{1}$, Raul I. Gutierrez-Calderon ${ }^{2}$, Mariano Cerca ${ }^{1}$, and Carlos F. Alcantara-Duran ${ }^{2}$ \\ ${ }^{1}$ Centro de Geociencias, Universidad Nacional Autónoma de México, \\ Santiago de Querétaro, PC 76230, Mexico \\ ${ }^{2}$ Coordinación de Evaluación de Riesgo, Iztapalapa, Mexico City, PC 09000, Mexico
}

Correspondence: Dora Carreon-Freyre (freyre@geociencias.unam.mx)

Published: 22 April 2020

\begin{abstract}
In spite of subsidence being a well-studied geological phenomenon in Mexico City, its effects and risks for urban infrastructure and inhabitants have been neglected. Damage in the short, medium and long term implies maintenance and important mitigation costs. There are not systematic studies that address methodologies for the estimation of physical vulnerability of the geological media to fracture. In this work, factors conditioning the deformation and susceptibility to fracturing are analyzed using a deterministic approach. The identified physical variables were mapped, measured and integrated into a database that allowed for an adequate correlation of the parameters that condition fractures spatial distribution. A methodology for estimating a vulnerability index to fracturing (VIF) useful for decision making is proposed in this work.
\end{abstract}

\section{Introduction}

According to historical reports, earth fissures and ground fractures affected the Mexico City subsoil before 1900 and have been studied since the mid-twentieth century. The persistent subsidence and the associated differential (Gayol, 1925) deformation have caused damage to housing and urban infrastructure, mainly to roads, water pipes and drainage. The first subsidence measurements and ground fractures developed after the beginning of groundwater extraction in the central part of the lacustrine plain were reported in 1925 . Since then, a total subsidence of $13 \mathrm{~m}$ has been reported at the center of Mexico City. Land subsidence was first numerically associated with groundwater extraction in the 1950s. The local authorities began to restrict groundwater pumping in the most affected areas nevertheless, and by the 1970s groundwater extraction was translated to the eastern side of the city (around the remnants of Lake Texcoco). With a fast-growing population and an increased need of water, ground fractures also developed in this zone, and by the 1990s fractures propagated and covered a larger area (Fig. 1).

Land subsidence has been widely studied in Mexico City during the last 5 decades (Zeevaert, 1953); nevertheless its effects in the mid and long term and risks for urban infrastructure and inhabitants have not yet been assessed properly. Damages in the long term implies maintenance and important mitigation costs (Carreon-Freyre et al., 2019). There are not systematic studies that address a methodology for the estimation of physical vulnerability to the fracture of the geological media. In this work, factors conditioning the deformation and susceptibility to fracturing are analyzed using a deterministic approach. A total subsidence of $13 \mathrm{~m}$ has been reported at the center of the lacustrine plain in Mexico City (Cabral-Cano et al., 2008; López-Quiroz et al., 2009).

Brittle fracturing of the near-surface clayey sediments of the lake has been attributed to subsidence related to high groundwater exploitation rates (Carrillo, 1947; CarreónFreyre et al., 2006; Ovando-Shelley et al., 2012). Surficial deformation features can be related to shallow groundwater flows, and, consequently, fractures open and close seasonally (Carreón Freyre, 2010; Carreon-Freyre et al., 2016; AguilarPérez et al., 2006). Moreover, a generalized consolidation state of thick clayey sequences related to deep groundwater depletion has been established; deep ground fracturing is a non-dilatant fracture in silts and clay sequences and may propagate through weak planes associated with lithological 


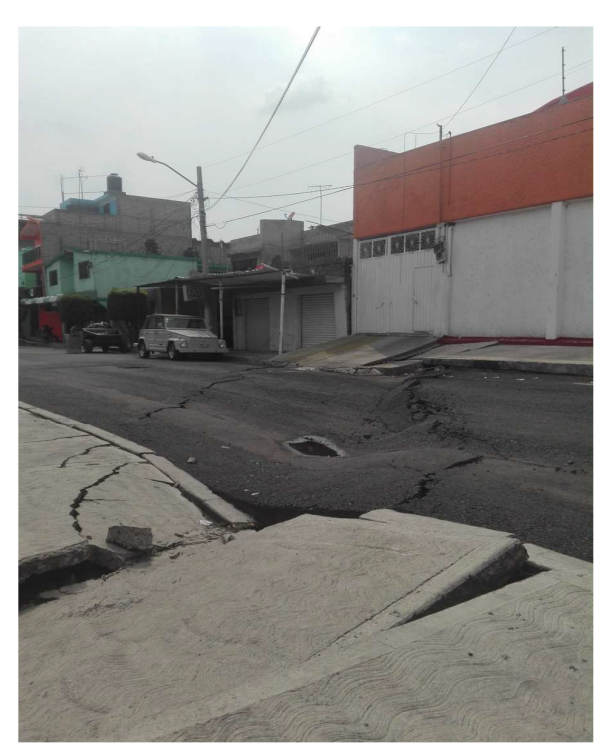

(a)

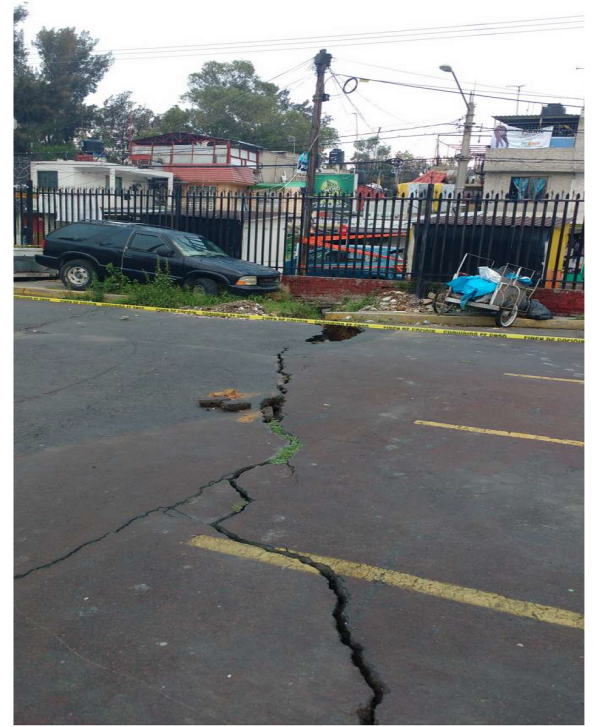

(b)

Figure 1. (a) Camarón Street fracture, Tláhuac, Mexico City. (b) Fracture in Albarradas, Iztapalapa, Mexico City.

contacts or major structural features from depth to the surface. A complex pattern of ground fractures dissects the lacustrine plain of Mexico City, which threatened the urban infrastructure. Recently the map of fractures was integrated into the Mexican National atlas of risks (Carreón Freyre et al., 2017) (Fig. 2).

\section{Physical variables conditioning physical vulnerability of the media to fracture development}

The general concept of physical vulnerability that considers a "degree of damage" can be defined differently in each discipline; for this work we consider the physical vulnerability as the "characteristic of the geological media that describes its susceptibility (or resistance) to the impact of the hazard of fracturing" in agreement with the definitions stated by the glossary presented in Schmidt-Thomé et al. (2007) and Kappes et al. (2012). The evaluation of physical vulnerability requires the implementation of an interdisciplinary methodology including: (a) the review of groundwater management, especially in urban areas; (b) detailed geological, hydrogeological and morphological characterization; and (c) the monitoring of groundwater piezometric evolution, land subsidence and ground differential displacements. The interdisciplinary analysis allows for a better understating of the triggering mechanisms of differential settlements, the generation and the propagation of ground fracturing (Ochoa-González et al., 2018).

According to previous studies ground fracturing is generated by the interaction of different factors (Carreon-Freyre et al., 2019): (1) geological preexisting discontinuities caused by variations in the depositional environment (Carreón-
Freyre et al., 2006); (2) stress history due to climate changes determining the geometry of early fracturing; (3) variations in the compressibility and permeability of geological materials that control short-term and local-scale deformation (Carreon-Freyre et al., 2016); and (4) the exhaustive exploitation of aquifers causing a decline of the pore water pressure leading to subsidence and creating vertical and horizontal tensile stresses (Carrillo, 1947; Rivera and Ledoux, 1991; Holzer, 1984; Juárez-Badillo and Figueroa Vega, 1984). The propagation of fractures is conditioned by the interaction of physical variables that can be mapped, measured and integrated into a database. Coexistence of one or several of the mentioned factors determines the mechanism of fracturing at diverse scales.

\section{Estimation of the vulnerability index to fracturing}

We have followed a deterministic approach and the indicatorbased methodology proposed by Kappes et al. (2012) for the study of multiple variables that can be mapped, measured and integrated into a database for spatial correlation analysis. For the development of the vulnerability index to fracturing (VIF) a weighted numerical analysis was performed to determine the potential areas of Mexico City that are prone to subside, develop ground fractures and/or present severe differential deformation (Fig. 3). Susceptibility of the variables was estimated and normalized for each variable that includes the addition of the weighted values: terrain slope from the geomorphologic map $\left(W_{\mathrm{gm}}\right)$, piezometric descent $\left(W_{\mathrm{pd}}\right)$, gradient of subsidence $\left(W_{\mathrm{gs}}\right)$, fracture type $\left(W_{\mathrm{f}}\right)$ and lithological variations or contacts $\left(W_{\text {lit }}\right)$, as shown in the following equation: 


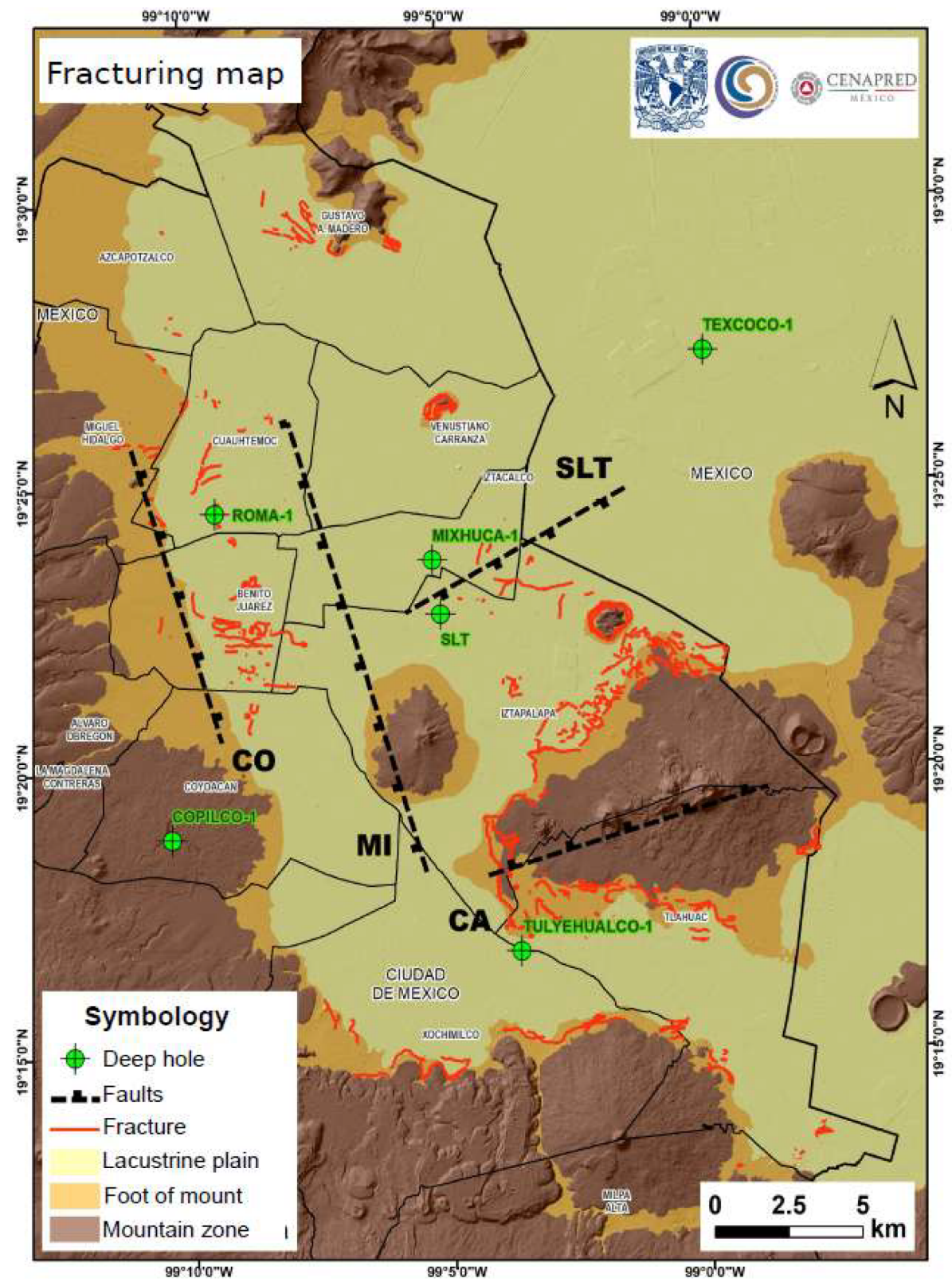

Figure 2. Ground fractures distribution in Mexico City (red lines) and main regional geological reported faults (black dotted lines) (Carreón Freyre et al., 2017).

$\mathrm{VIF}=\left[\sum_{i=0}^{n} W_{\mathrm{gm}}+W_{\mathrm{pd}}+W_{\mathrm{gs}}+W_{\mathrm{f}}+W_{\mathrm{lit}}\right] / n$

where $n$ is the number of variables.

The assignation of the weighted values considered a different percentage of the total amount recorded in the study area. For example, to estimate the "gradient of subsidence" $\left(g_{\mathrm{s}}\right)$, two tables were defined for absolute (Table 1) and weighted values (Table 2).

The spatial correlation of the physical variables allowed for identifying zones of fracture generation and estimating
Table 1. Rated values for the gradient of subsidence $\left(g_{\mathrm{S}}\right)$ in Mexico City.

\begin{tabular}{lr}
\hline Gradient of subsidence & Assigned value \\
\hline Low $(<4 \mathrm{~cm})$ & $0 \%$ \\
Medium $(4-12 \mathrm{~cm})$ & $65 \%$ \\
High $(>12 \mathrm{~cm})$ & $35 \%$ \\
\hline Total assigned value & $100 \%$ \\
\hline
\end{tabular}



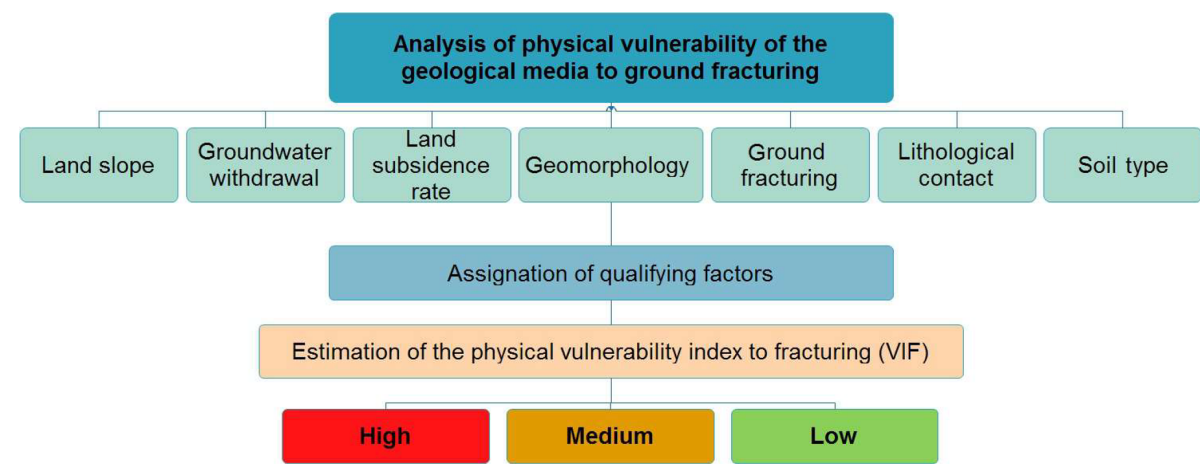

Figure 3. Flowchart for the determination of the physical vulnerability index to fracturing.

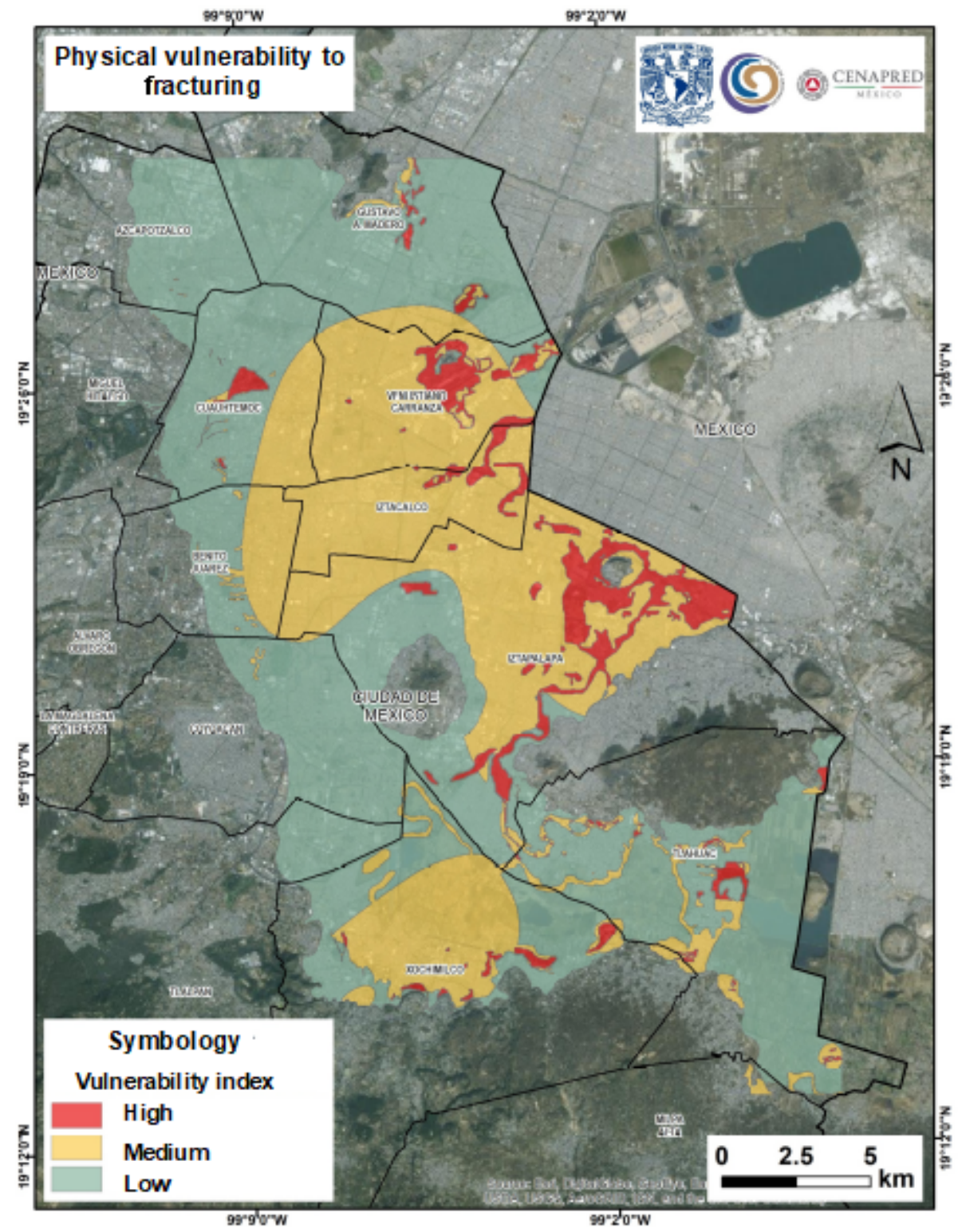

Figure 4. Mexico City distribution map of the physical vulnerability index to fracturing (Carreón Freyre et al., 2017). 
Table 2. Weighted values for the gradient of subsidence $\left(g_{\mathrm{s}}\right)$.

\begin{tabular}{lr}
\hline Gradient of subsidence & Weighted value $W_{\mathrm{gs}}$ \\
\hline Low $(<4 \mathrm{~cm})$ & $0 \%$ \\
Medium $(4-12 \mathrm{~cm})$ & $9.75 \%$ \\
High $(>12 \mathrm{~cm})$ & $5.25 \%$ \\
\hline Weight of the variable & $15 \%$ \\
\hline
\end{tabular}

Table 3. Rates of physical vulnerability to fracturing in the Mexico City area.

\begin{tabular}{lrr}
\hline Vulnerability level & Surface $\left(\mathrm{km}^{2}\right)$ & Percentage \\
\hline High & 23.9 & 3.9 \\
Medium & 143.8 & 23.6 \\
Low & 215.1 & 35.3 \\
No subsidence & 226.8 & 37.2 \\
\hline Total & 609.6 & 100 \\
\hline
\end{tabular}

propagation conditions (Fig. 4). The proposed vulnerability index to fracturing is easy to use for decision making and helps in the zoning of risk areas.

\section{Results: map of distribution of VIF in Mexico City}

The results of the analysis were integrated in a geographic information system and presented as a map defining three zones in Mexico City with values ranging from high to low physical vulnerability:

- High vulnerability represents a surface of $23.9 \mathrm{~km}^{2}$ (3.9\% of the area of Mexico City) located mainly at the eastern part of the city, with minor areas downtown and to the southern part.

- Medium vulnerability covers a surface of $144 \mathrm{~km}^{2}$ downtown and in the eastern and southern parts of Mexico City.

- Low vulnerability, with a surface of $215.1 \mathrm{~km}^{2}$, corresponds mainly to the rocky highlands of the western part of the city (Table 3).

\section{Conclusions}

Overexploitation of the aquifer has caused a continuous piezometric water level decline reaching about $50 \mathrm{~m}$ and up to $13 \mathrm{~m}$ of land subsidence in the central part of Mexico City. Consequently, the intensity of fracturing has increased and caused numerous problems to urban infrastructure. Estimations of infrastructure damage are in the order of several billion US dollars. This represents a great challenge for land and groundwater management in Mexico. We propose a deterministic methodology for the estimation of a vulnerability index to fracturing which is easy to use for zoning. The presented results are qualitative and cannot be analyzed statistically; nevertheless the VIF has shown to be very useful for decision making. The map can be a useful tool when assessing the related geological risk in Mexico City. The accuracy of the results should be improved with a larger database. Additionally, the VIF can be useful for the design of adequate monitoring systems aimed at the optimization of mitigation measures in the damaged sites.

Data availability. The database of the fracture map of Mexico City can be consulted at the CENAPRED public web site, in the section "Aplicaciones: Sistema de Información de Riesgos. Ciudad de México" http://www.atlasnacionalderiesgos.gob.mx/portal/ fenomenos/ (CENAPRED, 2020).

Author contributions. DCF and RGC designed the proposed methodology. MC supervised the analysis of geological information, and CAD created the map database. DCF prepared the paper with contributions from all co-authors.

Competing interests. The authors declare that they have no conflict of interest.

Special issue statement. This article is part of the special issue "TISOLS: the Tenth International Symposium On Land Subsidence - living with subsidence". It is a result of the Tenth International Symposium on Land Subsidence, Delft, the Netherlands, 17-21 May 2021.

Acknowledgements. The obtained results are part of the $\mathrm{Na}$ tional atlas of risks developed by the Centro Nacional de Prevención de Desastres (National Center of Disaster Prevention; CENAPRED) in Mexico and of the activities supported by the UNESCO IGCP 641 project.

Financial support. This research has been supported by the CENAPRED (grant no. CNPC/1183/2015). 


\section{References}

Aguilar-Perez, L. A., Ortega-Guerrero, M. A., Lugo-Hubp, J., and Ortiz-Zamora, D.: Análisis numérico acoplado de los desplazamientos verticales y generación de fracturas por extracción de agua subterránea en las proximidades de la Ciudad de México, Revista Mexicana de Ciencias Geológicas, 23, 247-261, ISSN 2007-2902, 2006.

Cabral-Cano, E., Dixon, T. H., Miralles-Wilhelm, F., SánchezZamora, O., Díaz-Molina, O., and Carande, R. E.: Space Geodetic Imaging of Rapid Ground Subsidence in México City, Bull. Geol. Soc. Am., 120, 1556-1566, https://doi.org/10.1130/B26001.1, 2008.

Carreón Freyre, D.: Keynote. Land subsidence processes and associated ground fracturing in Central Mexico, in: Land Subsidence, Associated Hazards and the Role of Natural Resources Development (Proceedings of EISOLS 2010, Querétaro, México), Red Book Series Publication 339, edited by: Carreón Freyre, D., Cerca, M. and Galloway, D. L., IAHS Press, CEH Wallingford, UK, 149-157, ISBN 978-1-907161-12-4, ISSN 0144-7815, 2010.

Carreon-Freyre, D., Cerca, M., Ochoa-Gonzalez, G., Teatini, P., and Zuñiga, R.: Shearing along faults and stratigraphic joints controlled by land subsidence and piezometric gradients in the Valley of Queretaro, Mexico, Hydrogeol. J., 24, 657-674, https://doi.org/10.1007/s10040-016-1384-0, 2016.

Carreón Freyre, D., Cerca Martinez, M., Gutierrez Calderón, R., and Alcántara Durán, C.: Análisis de vulnerabilidad física a la subsidencia, hundimiento y agrietamiento en la Ciudad de México, Report, National Atlas of Risks Centro Nacional de Prevención de Desastres (CENAPRED), Aplicaciones/Sistema de Información sobre Riesgos/Ciudad de México, available at: https:// cordis.europa.eu/project/id/511208 (last access: 30 March 2020), 2017.

Carreon-Freyre, D., Cerca, M., Gutierrez-Calderon, R., AlcantaraDuran, C., Strozzi, T., and Teatini, P.: Land Subsidence and associated ground fracturing in urban areas, Study cases in central Mexico, in: Proceedings of the XVI Pan-American Conference on Soil Mechanics and Geotechnical Engineering, Cancun, México, 17-20 November 2019, 9 pp., 2019.

Carreón-Freyre, D. C., Hidalgo-Moreno, C., and Hernández-Marín, M.: Mecanismos de fracturamiento de depósitos arcillosos en zonas urbanas. Caso de deformación diferencial en Chalco, Estado de México, Boletín de la Sociedad Geológica Mexicana, Número Especial de Geología Urbana, Tomo, LVIII, 237-250, 2006.

Carrillo, N.: Influence of artesial wells in the sinking of Mexico City, in: Volumen Nabor Carrillo: El hundimiento de la Ciudad de México y el Proyecto Texcoco, Com. Impulsora y Coordinadora de la Investigación Científica Anuario, 47, 7-14, 1947.

Centro Nacional de Prevención de Desastres (CENAPRED): Atlas Nacional de Riesgos, available at: http://www.atlasnacionalderiesgos.gob.mx/portal/fenomenos/, last access: 30 March 2020.
Gayol, R.: Estudio de las perturbaciones que en el fondo de la Ciudad de México ha producido el drenaje de las aguas del subsuelo, por las obras del desagüe y rectificación de los errores a que ha dado lugar una incorrecta interpretación de los efectos producidos, Revista Mexicana de Ingeniería y Arquitectura, III, 96-132, 1925.

Holzer, T. L.: Ground failure induced by groundwater withdrawal from unconsolidated sediments, Rev. Eng. Geol., 6, 67-105, 1984.

INEGI: Intercensal Survey (Encuesta Intercensal 2015). Instituto Nacional de Estadistica y Geografia, 96 pp., available at: https://www.inegi.org.mx/programas/intercensal/2015/ (last access: 30 March 2020), 2015.

Juárez-Badillo, E. and Figueroa Vega, G. E.: Stresses and displacements in an aquifer due to seepage forces (one dimensional case), J. Hydrol., 73, 259-288, 1984.

Kappes, M. S., Papathoma-Köhle, M., and Keiler, M.: Assessing physical vulnerability for multi-hazards using an indicator-based methodology, Appl. Geogr., 32, 577-590, https://doi.org/10.1016/j.apgeog.2011.07.002, 2012.

López-Quiroz, P., Doin, M. P., Tupin, F., Briole, P., and Nicolas, J. M.: Time series analysis of Mexico City subsidence constrained by radar interferometry, J. Appl. Geophys., 69, 1-15, https://doi.org/10.1016/j.jappgeo.2009.02.006, 2009.

Ochoa González, G. H., Carreón-Freyre, D., Franceschini, A., Cerca, M., and Teatini, P.: Overexploitation of groundwater resources in the faulted basin of Querétaro, Mexico: A 3D deformation and stress analysis, Eng. Geol., 245, 192-206, https://doi.org/10.1016/j.enggeo.2018.08.014, 2018.

Ovando-Shelley, E., Lermo-Samaniego, J., Auvinet, G., and Méndez-Sánchez, E.: Microtremor measurements to identify zones of potential fissuring in the basin of Mexico, Geofísica Internacional, 51-2, 143-156, 2012.

Rivera, A. and Ledoux, E.: Non-Linear modeling of groundwater flow and total subsidence in the Mexico City aquifer-aquitard system, in: P. Fourth Int. Symp. Land Subsidence, IAHS, 12 17 May 1991, Houston, Texas, USA, 45-58, 1991.

Schmidt-Thomé, P., Klein, J., Aumo, R., and Hurstinen, J.: Report: Technical Glossary of a Multi Hazard Related Vulnerability and Risk Assessment Language - Final version, Armonia Project, Contract No. 511208, Applied Multi-Risk Mapping of Natural Hazards for Impact Assessment, Geological Survey of Finland (GTK), available at: https://www.umweltbundesamt.de/en/topics/climateenergy/climate-change (last access: 30 March 2020), 2007.

Zeevaert, L.: Stratigraphy and engineering problems in the lacustrine clayey deposits of Mexico City, Memoria del Congreso Científico Mexicano, 5, 58-70, 1953. 